\title{
Penghambatan Oksidasi Lipid Minyak Ikan Cakalang (Katsuwonus pelamis) Oleh Air Jahe (Zingiber officinale var. rubrum) Selama Penyimpanan Dingin
}

\author{
Ilevena R. M. Josef*a, Ardi Kapahang ${ }^{a}$, Dokri Gumolung ${ }^{b}$
}

Kimia, Universitas Negeri Manado, Tondano, 95618, Indonesia

INFO ARTIKEL

Diterima 02 September 2019

Disetujui 14 Oktober 2019

Key word:

Fish oil

Antioxidant

Peroxide value

Free fatty acid

Kata kunci:

Minyak ikan

Antioksidan

Bilangan peroksida

Asam lemak bebas

${ }^{*}$ e-mail:josefilevena@gmail.com

*Telp:089665238510

\begin{abstract}
A BSTRACT
Fish is one of the main foods for humans that are rich of proteins, fatty, and minerals that are good for health. Unsaturated fatty acids are very easily oxidized by the presence of catalysts such as oxygen, heat, light, and the presence of metals. Ginger contains antioxidants which can inhibit oxidation of fat or oil. This study aims to inhibit fat oxidation of skipjack fish with the addition of ginger. Skipjack fish soaked in ginger water with a concentration of $10 \%, 20 \%, 30 \%$ and the control, then saved for $0,2,4$ days. The fish was extracted by the wet rendering method and then analyzed with 2 parameters, peroxide value and free fatty acids with the titration method. The best concentration in inhibiting lipid oxidation of skipjack fish is at a concentration of $10 \%$ and $30 \%$. The peroxide value of skipjack tuna oils is still below the IFOS standard of $3.75 \mathrm{meq} \mathrm{O} / \mathrm{kg}$ and the percentage of free fatty acids is still below the standard of $1.5 \%$
\end{abstract}

\begin{abstract}
A BSTRAK
Ikan merupakan salah satu makanan utama bagi manusia yang kaya akan protein, lemak, vitamin dan mineral yang baik untuk kesehatan. Asam lemak tak jenuh sangat mudah teroksidasi dengan adanya katalisator seperti oksigen, panas, cahaya, keberadaan logam, dan sebagainya. Jahe merah mengandung antioksidan yang dapat menghambat oksidasi lemak atau minyak. Penelitian ini bertujuan untuk menghambat oksidasi lemak ikan cakalang dengan penambahan jahe merah. Ikan cakalang direndam dalam air jahe dengan konsentrasi 10\%, 20\%, 30\% dan kontrol kemudian disimpan selama 0 hari, 2 hari dan 4 hari. Ikan diesktraksi dengan metode wet rendering kemudian dianalisis dengan 2 parameter yaitu bilangan peroksida dan asam lemak bebas dengan metode titrasi. Konsentrasi terbaik dalam menghambat oksidasi lipid ikan cakalang terdapat pada konsentrasi $10 \%$ dan 30 . Bilangan peroksida minyak ikan cakalang masih berada dibawah standar IFOS yaitu 3,75 meq $\mathrm{O}_{2} / \mathrm{kg}$ dan persentase asam lemak bebas yang diperoleh pada kontrol dan semua konsentrasi memiliki kualitas yang baik dan masih berada dibawah standar IFOS yaitu 1,5\%.
\end{abstract}

\section{Pendahuluan}

Ikan merupakan salah satu sumber protein dan juga memiliki kandungan gizi yang tinggi diantaranya mengandung mineral, vitamin, dan lemak tak jenuh[1].

Ikan sangat rentan terhadap oksidasi karena mengandung asam lemak. Kandungan asam lemak tak jenuh mengakibatkan daging ikan mudah mengalami proses oksidasi sehingga menyebabkan bau tengik. Proses pembusukan pada ikan juga disebabkan oleh enzim, mikroorganisme, dan oksidasi dalam tubuh ikan itu sendiri dengan perubahan seperti timbul bau busuk, daging menjadi kaku, sorot mata pudar, serta adanya lendir pada insang maupun tubuh bagian luar [2]. 
Salah satu ikan yang banyak dikonsumsi oleh masyarakat di Sulawesi Utara adalah ikan cakalang. Ikan cakalang memiliki berbagai macam manfaat, namun ikan cakalang juga termasuk komoditas yang cepat rusak. Lipid ikan sangat sensitif terhadap oksidasi karena mengandung asam lemak tidak jenuh omega-3. Asam lemak tidak jenuh seperti asam eikosapentaenoat dan asam dokosapentaenoat dapat teroksidasi dengan mudah oleh berbagai katalisator seperti oksigen, panas, cahaya, keberadaan logam, dan sebagainya [3].

Penyimpanan ikan dengan waktu yang lama dapat membuat ikan menjadi tengik. Semakin lama penyimpanan maka semakin banyak reaksi oksidasi yang terjadi. Asam lemak tak jenuh pada ikan biasanya teroksidasi pada awal penyimpanan. Penyimpanan ikan dengan suhu dingin dapat mempertahankan mutu ikan. Mutu ikan berkaitan dengan tingkat kesegaran ikan. Proses penurunan mutu (deteriosasi) pada ikan disebabkan oleh reaksi autolisis, kimiawi, dan bakteriologis [4].

Pendinginan merupakan salah satu cara pengawetan yang menggunakan suhu rendah untuk menghambat aktivitas enzim dan mikroba. Pendinginan akan memperpanjang masa simpan ikan [5].

Reaksi oksidasi dimulai dengan pembentukkan radikal bebas yaitu peroksida aktif dan hidrogen peroksida, dan tingkat selanjutnya yaitu terurainya asam-asam lemak serta konversi hidrogen peroksida menjadi aldehid dan keton serta asam-asam lemak rantai pendek [6].

Antioksidan adalah senyawa yang dapat menghambat oksidasi. Senyawa antioksidan yang sering digunakan terdiri dari antioksidan sintesis dan antioksidan alami, tetapi antioksidan sintesis diduga menimbulkan efek negatif bagi kesehatan seperti menyebabkan kanker. Antioksidan sintetik yang biasanya ditambahakan pada minyak dan lemak adalah butylated hidroxy anisole (BHA), butylated hidroxy toluene (BHBT), dan tertiary butylated hydroxyl quinine (TBHQ). Penggunaan antioksidan sintetik jika berlebihan maka akan menyebabkan keracunan, sedangkan dalam dosis yang rendah secara terus menerus akan menyebabkan tumor kandung kemih, kanker sekitar lambung dan kanker paru-paru [7].
Antioksidan sintetik BHA dan BHT berpotensi karsinogenik[8].

Salah satu contoh antioksidan alami adalah jahe merah. Jahe merah merupakan salah satu rempah-rempah yang dikenal luas oleh masyarakat Indonesia. Kandungan senyawa aktif non volatil fenol seperti gingerol, shogaol dan zingeron, yang terdapat pada jahe terbukti memiliki kemampuan sebagai antioksidan. Gingerol dan shogaol yang merupakan antioksidan nonenzimatik mampu bertindak sebagai antioksidan primer terhadap radikal lipid $[9,10]$.

Antioksidan dapat juga memperpanjang umur simpan bahan pangan karena antioksidan dapat dijadikan sebagai pengawet. Antioksidan adalah inhibitor yang dapat menghentikan reaksi oksidasi dengan mencegah terjadinya radikal bebas atau dengan menetralisir radikal bebas [11].

\section{Bahan dan Metode}

Peralatan yang akan digunakan dalam penelitian ini di antaranya : wadah stanles steel, labu ukur, timbangan, labu erlenmeyer, alat titrasi, hotplate, tabung reaksi, aluminium foil, termometer, refrigerator, cooling box, juicer, sendok, gelas, botol vial. Bahan penelitian yang digunakan yaitu ikan cakalang, jahe merah, kloroform, asam asetat glasial, KI, akuades, indikator amilum, indikator fenolftalein, natrium thiosulfat, etanol 95\%, kalium hidroksida, $\mathrm{HCl} 2 \mathrm{~N}$, asam oksalat $0,1 \mathrm{~N}$, kalium dikromat.

\section{Prosedur Kerja}

Preparasi sampel

Sampel yang digunakan pada penelitian ini yaitu ikan cakalang, yang diambil dari dermaga Belang, Sulawesi Utara. Sampel disiangi, dicuci bersih, dan direndam dalam ekstrak air jahe dengan konsentrasi 10\%, 20\%, 30\% dan kontrol (tanpa perendaman) sebagai pembanding, ikan dimasukkan ke dalam plastik dan disimpan dalam refrigerator selama 2 dan 4 hari.

\section{Ekstraksi Minyak Ikan Wet Rendering (Telah dimodifikasi)}

Sebanyak $1,7 \mathrm{~kg}$ ikan cakalang dikukus dengan suhu $100^{\circ} \mathrm{C}$ selama 30 menit kemudian 
didinginkan. Ikan cakalan diperas dan diambil minyaknya [12].

\section{Penentuan Asam Lemak Bebas}

Sebanyak 1 gr minyak ikan dimasukkan kedalam erlenmeyer $250 \mathrm{ml}$ dan ditambahkan dengan $25 \mathrm{ml}$ etanol netral kemudian dipanaskan diatas penangas air selama 10 menit dan didinginkan. Tambahkan indikator phenolptalein sebanyak 2 tetes dan dikocok kemudian dititrasi dengan larutan $\mathrm{KOH} \mathrm{0,1} \mathrm{N}$. titrasi dihentikan saat terjadi perubahan warna merah muda yang tidak hilang selama 10 detik [13].

\section{Penentuan Bilangan Peroksida}

Sebanyak 1 gr minyak ikan dimasukkan kedalam erlenmeyer $250 \mathrm{ml}$ dan ditambahkan larutan asam asetat glasial : kloroform (3:2) sebanyak $30 \mathrm{ml}$. Tambahakan 0,5 ml larutan KI jenuh dan $30 \mathrm{ml}$ akuades, kemudian dikocok selama 1 menit. Diamkan dalam ruangan gelap selama 15 menit kemudian dititrasi dengan larutan $\mathrm{Na}_{2} \mathrm{~S}_{2} \mathrm{O}_{3} \quad 0,1 \quad \mathrm{~N}$ dan ditambahkan indikator amilum $1 \%$ sebanyak $0,5 \mathrm{ml}$. Titrasi dihentikan saat warna biru pada larutan hilang [13].

\section{Hasil dan Pembahasan \\ Ekstraksi Minyak Ikan}

Minyak ikan cakalang dibuat dengan metode wet rendering (ekstraksi basah) dengan suhu $100^{\circ} \mathrm{C}$. Sebelum pembuatan minyak, ikan diberi perlakuan dengan cara direndam dalam air jahe dengan konsentrasi 10\%, 20\%, dan 30\% selama 1 jam dan di simpan dalam kulkas dengan suhu $5^{\circ} \mathrm{C}$ dengan variasi hari penyimpanan 0 hari, 2 hari dan 4 hari. Minyak ikan diperoleh dengan cara di kukus dengan suhu $100^{\circ} \mathrm{C}$ selama 30 menit, diperas hingga minyak dan airnya keluar, dan minyak dipisahkan dengan cara dibekukan kemudian diambil bagian atas yaitu bagian minyaknya dan dicairkan dengan cara dipanaskan di atas penangas air.

Ikan cakalang yang digunakan memiliki bobot rata-rata $1,7 \mathrm{~kg}$ menghasilkan minyak sebanyak 9,2365 gram. Minyak yang dihasilkan kemudian diuji dengan 2 parameter yaitu bilangan peroksida dan asam lemak bebas dengan 3 kali pengulangan.

\section{Bilangan Peroksida}

Bilangan peroksida merupakan tolak ukur kerusakan atau ketengikan suatu minyak. Semakin tinggi bilangan peroksida maka semakin tengik minyak tersebut [14].

Tabel 1. Bilangan peroksida minyak ikan cakalang

\begin{tabular}{ccccc}
\hline Hari & Kontrol & $10 \%$ & $20 \%$ & $30 \%$ \\
\hline 0 & $0,02 \pm 0,006$ & $0.02 \pm 0.005$ & $0.03 \pm 0.021$ & $0.01 \pm 0.006$ \\
2 & $0.01 \pm 0.012$ & $0.02 \pm 0.010$ & $0.01 \pm 0.006$ & $0.01 \pm 0.0001$ \\
4 & $0.02 \pm 0.010$ & $0.01 \pm 0.006$ & $0.02 \pm 0.0001$ & $0.02 \pm 0.005$ \\
\hline
\end{tabular}

Dari data pengujian bilangan peroksida, hari penyimpanan ke-0, ke-2, ke-4 kontrol, konsentrasi $10 \%, 20 \%, 30 \%$ masih dibawah standar yang telah ditetapkan oleh IFOS (International Fish Oil Standard) yaitu $\leq 3,75 \mathrm{meq}$ $\mathrm{O}_{2} / \mathrm{kg}$. Hal ini disebabkan oleh suhu penyimpanan minyak ikan yang disimpan pada penyimpanan dingin dan disebabkan oleh penambahan antioksidan alami berupa jahe merah yang dapat menghambat proses oksidasi.

Senyawa aktif non volatil fenol seperti gingerol dan shogaol dan senyawa turunannya yang terdapat pada jahe terbukti memiliki aktivitas antioksidan. Senyawa fenolik dapat berfungsi sebagai antioksidan karena kemampuannya dalam menstabilkan radikal bebas dengan memberikan atom hidrogen kepada radikal bebas. Senyawa fenol merupakan suatu senyawa yang memiliki cincin aromatik dengan satu atau lebih gugus hidroksil yang berfungsi sebagai antioksidan ${ }^{[9]}$.

Antioksidan mampu menghambat terbentuknya radikal bebas pada tahap inisiasi dan menghambat kelanjutan reaksi autooksidasi pada tahap propagasi. Hal ini karena antioksidan memiliki energi aktivasi yang rendah untuk melepaskan satu atom hidrogen kepada radikal lemak sehingga tahap lebih lanjut dapat dicegah [14].

Gambar 1 menunjukan bilangan peroksida minyak ikan cakalang, dimana konsentrasi $20 \%$ dan $30 \%$ mengalami penurunan dihari penyimpanan ke-2 dan kenaikan dihari penyimpanan ke-4. Konsentrasi $10 \%$ semakin hari semakin menurun. 
Pemberian air jahe memberikan pengaruh terhadap oksidasi lipid minyak ikan cakalang.

Angka peroksida yang lebih rendah bukan berarti menunjukan kondisi oksidasi yang masih berjalan pada tahap awal tetapi dimungkinkan produk hasil oksidasi lemak terurai menjadi senyawa lain pada tingkat oksidasi lanjut [15].

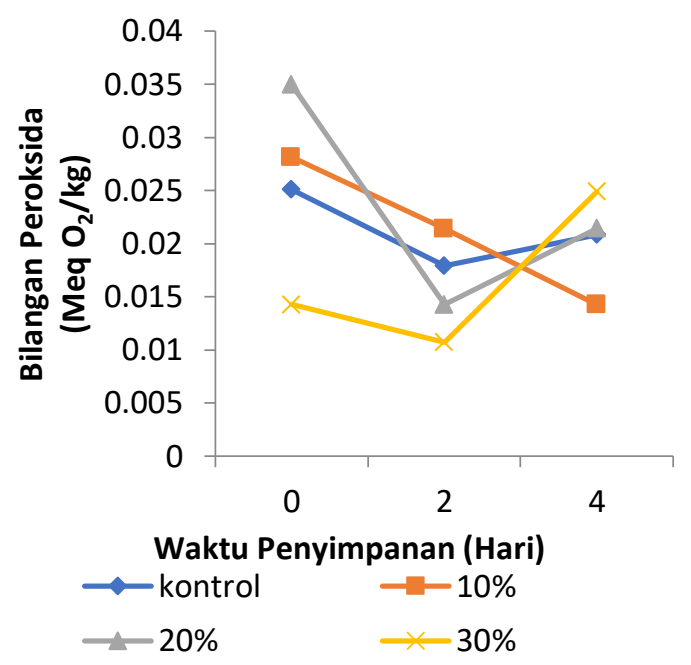

Gambar 1. Grafik bilangan peroksida minyak ikan cakalang

Pada saat penyimpanan dalam jangka waktu yang lama, kualitas dan kesegaran ikan akan menurun. Kandungan asam lemak tak jenuh didalam tubuh ikan cakalang lebih didominasikan oleh asam lemak tak jenuh majemuk (PUFA) sehingga minyak ikan rentan mengalami ketengikan oksidatif. Lemak yang mengandung PUFA yang tinggi sangat mudah mengalami oksidasi pada saat penyimpanan [16]. Oksidasi minyak ikan meningkat seiring dengan lamanya penyimpanan, hal ini terjadi karena proses hidrolisis trigliserida pada minyak dan serta oksidasi pada ikatan rangkap asam lemak [17].

\section{Asam Lemak Bebas}

Asam lemak bebas dihasilkan oleh proses hidrolisis dan oksigen biasanya bergabung dengan lemak netral [18]. Kadar asam lemak bebas merupakan indikator untuk mengetahui banyaknya kadar asam lemak bebas dalam minyak ikan.

Asam lemak bebas dihasilkan dari asam lemak tidak jenuh, maka akan memperbesar terjadinya oksidasi bila tersedia cukup oksigen [19].

\begin{tabular}{ccccc}
\hline Hari & Kontrol & $10 \%$ & $20 \%$ & $30 \%$ \\
\hline 0 & $0.51 \pm 0.22$ & $0.80 \pm 0.11$ & $0.5758 \pm 0.13$ & $1.10 \pm 0.17$ \\
2 & $0.86 \pm 0.10$ & $0.72 \pm 0.04$ & $0.62 \pm 0.25$ & $1.07 \pm 0.09$ \\
4 & $0.92 \pm 0.09$ & $0.83 \pm 0.11$ & $0.84 \pm 0.38$ & $0.84 \pm 0.08$ \\
\hline
\end{tabular}

Tabel 2. Persentase asam lemak bebas minyak ikan cakalang

Pengujian asam lemak bebas minyak ikan cakalang menunjukan kadar yang rendah yang masih sesuai dengan standar yang telah ditentukan oleh IFOS (International Fish Oil Standard) yaitu $1,5 \%$.

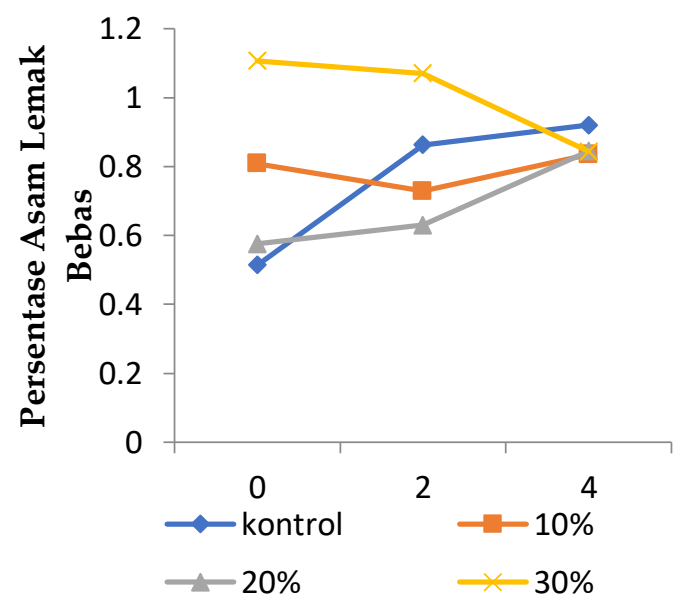

Gambar 2. Grafik persentase asam lemak bebas minyak ikan cakalang

Gambar 2 menunjukan nilai asam lemak bebas antara kontrol dengan konsentrasi jahe $10 \%$, 20\%, dan $30 \%$, dimana pada hari pertama nilai asam lemak bebas konsentrasi $10 \%, 20 \%$, dan 30\% lebih tinggi dari kontrol, sedangkan hari kedua dan keempat konsentrasi 10\% dan $20 \%$ dan nilainya ada dibawah kontrol. Hal ini karena adanya antioksidan dalam minyak ikan sehingga nilai asam lemak bebasnya lebih rendah dibandingkan kontrol.

Peningkatan nilai asam lemak bebas terjadi pada kontrol, dimana semakin hari semakin tinggi nilai asam lemak bebasnya. Hal ini karena tidak ada penambahan antioksidan pada ikan sehingga semakin hari asam lemak bebas samakin meningkat.

Asam lemak bebas dengan konsentrasi 30\% semakin hari semakin menurun. Hal ini karena konsentrasi jahe yang tinggi sehingga semakin 
lama penyimpanan semakin turun kadar asam lemak bebas. Reaksi pembentukan asam lemak bebas dipercepat dengan adanya panas, air, keasaman, dan katalis enzim. Semakin lama proses ini berlangsung maka semakin meningkat jumlah asam lemak bebas [19].

\section{Ucapan terimakasih}

Penulis mengucapkan terimakasih atas bantuan dan bimbimngan dari pembimbing I dan pembimbing II yaitu Dr. Ir. Ardi Kapahang, M.Si dan Drs. Dokri Gumolung, M.Si dan untuk semua pihak yang sudah membantu penulis dalam melakukan penelitian hingga penulisan artikel.

\section{Kesimpulan}

Pemberian air jahe memberikan pengaruh terhadap lipid ikan cakalang karena dapat menekan kenaikan bilangan peroksida dan asam lemak bebas.

Konsentrasi terbaik dalam menghambat oksidasi terdapat pada konsentrasi $10 \%$ dan $30 \%$

\section{DaftarPustaka}

1. Bahalwan, Farida. Analisis Kadar Protein Pada Bakasang Pada Jeroan Ikan Cakalang (Katsuwonus pelamis, Lin). Biology And Education, 2013, 89-95.

2. Estiasih, T. Minyak Ikan Tegnologi dan Penerapannya untuk Pangan dan Kesehatan. Yogyakarta: Graha Ilmu, 2009.

3. Harikedua, S. D. Penghambatan Oksidasi Lipida Ikan Tuna Oleh Air Jahe Selama Penyimpanan Dingin. Jurnal Perikanan dan Kelautan Tropis, 2012, 7-11

4. Sohn, H. H; Taki, Y; Ushio, H; Kohata, T; Shioya I; Oshima, T. Lipid Oxidations in Ordinary and Dark Muscles of Fish: Influences on Rancid Off-odor Development and Color Darkening of Yellowtail Flesh During Ice Storage. Journal Food Science, 2005: S490-S496.

5. Sitakar, N. M; Nurliana; Jamin, F; Abrar, M; Manaf, Z. H; Sugito. Pengaruh Suhu Pemeliharaan dan Masa Simpan Daging Ikan Nila (Oreochromis niloticus) Pada Penyimpanan Suhu $-20^{\circ} \mathrm{C}$ Terhadap
Jumlah Total Bakteri. Jurnal Medika Veterinaria, 2016, 162-165

6. Ketaren, S. Minyak dan Lemak Pangan. University Of Indonesia. 1986 Press: Jakarta. 315 hal

7. Cahyadi, W. Analisis dan Aspek Kesehatan Bahan Tanaman Pangan. PT Bumi Aksara. Jakarta. 2006

8. Jacoeb, A. M; Sri, P; Rinto, Anatomi. Komponen Bioaktif dan Aktivitas Antioksidan Daun Mangrove Api-api (Avicena marina). Jurnal Pengolahan Hasil Perikanan Indonesia, 2011, 143-152.

9. Aloanis, A. A.; Karundeng, M., Total kandungan antioksidan ekstrak etanol buah beringin (Ficus benjamina Linn.). Fullerene Journal of Chemistry. 2019. 4(1):1-4.

10. Kikuzaki, H. dan Nakatami, N. Antiokxidant Effects Of Some Ginger Constituents. Journal of Food Science. 1993 :1407-1410

11. Puspasari, A. R., Dewi, E. N., Rianingsih, L. "Aplikasi Antioksidan Dari Ekstrak Lamun (Cymodocea rotundata) pada Minyak Ikan Tongkol (Euthynnus ainis)." Agritech, 2017: $115-120$

12. Lestari, N; Susanty, A; Kurniawaty. Penggunaan Natrium Klorida $(\mathrm{NaCl})$ Dan Asam Fosfat $\left(\mathrm{H}_{3} \mathrm{PO}_{4}\right)$ Pada Proses Degguming Untuk Pemurnian Minyak Kasar Ikan Patin (Pangasius sp.) Journal of Agro-based Industry, 2008, 29-37

13. Association Of Official Analytical and Chemistry. Official Method of Analysis of The Association of Official Analytical of Chemist. Arlington Virginia (US): Association of Analytical and Chemist, Inc. 2005

14. Apriyani, Tias. Efek Penambahan Antioksidan Terhadap Sifat Sensori Dan Lama Simpan Roti Tawar Yang Difotifikasi Dengan Minyak Ikan. Skripsi, Universitas Lampung, Bandar Lampung, 2016

15. Dewi, E. N; R. Ibrahim; N, Yuaniva. Daya Simpan Abon Ikan Nila Merah (Oreochromis niloticus Trewavas) Yang Diproses Dengan Metode Penggorengan Berbeda. Jurnal Saintek Perikanan, 2011, 6-12

16. Toisuta, Raymond Boyke. Karakterisasi Minyak Ikan Dari Hasil Samping Ikan 
Cakalang (Katsuwonus pelamis). Skripsi, Institut Pertanian Bogor, Bogor, 2014.

17. Crexi, V. T; Monte, M. L; Soares, L. A. S; Pinto, L. A. A. Production and Refinement of Oil from Carp (Cyprinus carpio) Viscera. Journal Food Chem, 2010: 119: 945-950

18. Musbah, Muhamad. Produk Emulsi Dari Kombinasi Minyak Ikan Sardin (Sardinella sp.) Dan Cucut (Centrophorus sp.). Skripsi, Institut Pertaniain Bogor, Bogor, 2017.

19. Ahmadi, K. Pemurnian Minyak Ikan Hasil Samping Penepungan Ikan Lemuru (Sardinella longiceps) Menggunakan Zeolit Alam Teraktivasi. UPN Jatim, Repository 1(1): 93-102

20. Gunawan,. Triatmo,. Rahayu, A. Analisis pangan: penentuan angka peroksida dan asam lemak bebas pada minyak kedelai dengan variasi menggoreng. Jurnal Kimia Analitik. 2003 :1-6. 